\title{
Hubungan Titer Widal Dengan Jumlah Limfosit Dan Trombosit Pada Pasien Demam Typhoid Di Puskesmas Gunungsari Lombok Barat
}

\author{
Fitriyani, Iswari Pauzi, Yudha Anggit Jiwantoro \\ Jurusan Analis Kesehatan Poltekkes Kemenkes Mataram, Indonesia
}

\section{Article Info}

\section{Article history:}

Received Aug $10^{\text {th }}, 2021$

Revised Aug $30^{\text {th }}, 2021$

Accepted Sep 01 ${ }^{\text {st }}, 2021$

\section{Keyword:}

Typhoid Fever,

Widal,

Lymphocytes,

Platelets

\begin{abstract}
Typhoid fever is a bacterial infection caused by Salmonella typhi. Salmonella typhi infection is bacteremic that enters the intestine and then spreads to the bone marrow. Diagnosis of Samonella typhi using Widal test and routine blood tests. Widal test and routine blood tests to see the body's mechanism against lymphocytes and platelets which are produced in the bone marrow and work as the body's defense against infectious infections. When these bacteria reach the bone marrow, it will inhibit the formation of lymphocytes and platelets. This is also due to the presence of endotoxin from bacteria so that in the case of typhoid fever, lymphocytosis and thrombocytopenia occur. Objective: To determine the relationship between Widal titer and the number of lymphocytes and platelets in patients with typhoid fever. Research method: Analytical Observation. The number of samples used as many as 24 samples using primary data. The data collected is in the form of Widal titer with lymphocytes and platelets. Then processed using the Person Correlation statistical test. Results: The mean lymphocyte on the $\mathrm{O}$ antigen with a titer of $1 / 160$ is $24.84 \%$, a titer of $1 / 320$ is $43.95 \%$, the mean of platelets with a titer of $1 / 160$ is $312,000 \mathrm{~L}$ and a titer of $1 / 320$ is $230,750 \mathrm{~L}$. antigen $\mathrm{H}$, the mean number of lymphocytes with a titer of $1 / 160$ is $35.48 \%$ and a titer of $1 / 320$ is $39.86 \%$. The mean platelet count with a titer of $1 / 160$ was $196,670 \mathrm{~L}$ and a titer of $1 / 320$ was $158,000 \mathrm{~L}$. The result of statistical test was $p>0.05$. Conclusion: There is no relationship between Widal titer and the number of lymphocytes and platelets in typhoid fever patients at Gunungsari Health Center, West Lombok.
\end{abstract}

\begin{abstract}
ABSTRAK
Demam typhoid merupakan infeksi bakteri yang disebabkan oleh Salmonella typhi. Infeksi Salmonella typhi bersifat bakterimia yang masuk ke dalam usus halus kemudian menyebar ke sumsum tulang. Diagnosis Samonella typhi menggunakan uji widal dan pemeriksaan darah rutin. Uji Widal dan pemeriksaan darah rutin untuk melihat mekanisme tubuh terhadap limfosit dan trombosit yang diproduksi di sumsum tulang dan berfungsi sebagai pertahanan tubuh terhadap adanya infeksi. Bila bakteri ini sampai ke sumsum tulang maka akan menghambat pembentukan limfosit dan trombosit. Hal ini juga disebabkan adanya endotoksin dari bakteri sehingga pada kasus demam typhoid terjadinya limfositosis dan trombositopenia. Tujuan penelitian: Mengetahui hubungan titer widal dengan jumlah limfosit dan trombosit pada pasien demam typhoid. Metode penelitian: Observasional Analitik. Jumlah sampel yang digunakan sebanyak 24 sampel dengan menggunakan data primer. Data yang dikumpulkan berupa titer widal dengan jumlah limfosit dan trombosit. Kemudian diolah menggunakan uji statistik Korelasi Person. Hasil Penelitian: Rerata limfosit pada antigen $\mathrm{O}$ dengan titer $1 / 160$ adalah $24,84 \%$, titer $1 / 320$ adalah $43,95 \%$, rerata trombosit dengan titer $1 / 160$ adalah $312.000 \mu \mathrm{L}$ dan titer $1 / 320$ adalah $230.750 \mu \mathrm{L}$. Sedangkan pada antigen $\mathrm{H}$ rerata jumlah limfosit dengan titer $1 / 160$ adalah $35,48 \%$ dan titer $1 / 320$ adalah $39,86 \%$. Rerata jumlah trombosit dengan titer $1 / 160$ adalah $196.670 \mu \mathrm{L}$ dan titer $1 / 320$ adalah $158.000 \mu \mathrm{L}$. Hasil uji statistik p>0,05. Kesimpulan: Tidak terdapat hubungan titer widal dengan jumlah limfosit dan trombosit pada pasien demam typhoid di Puskesmas Gunungsari Lombok Barat.
\end{abstract}

Kata Kunci : Demam Typhoid, Widal, Limfosit, Trombosit 


\section{Pendahuluan}

Demam typhoid merupakan infeksi bakteri yang disebabkan oleh Salmonella typhi yang dijumpai di berbagai negara berkembang terutama di daerah tropis dan subtropis. Penyakit ini ditularkan melalui makanan atau minuman yang terkontaminasi oleh tinja atau urin orang yang terinfeksi. Kelompok penyakit ini merupakan penyakit yang mudah menular dan menyerang banyak orang terutama pada anak - anak (Maulida, et al 2015). Penyebaran penyakit ini berkaitan erat dengan kepadatan penduduk, kebersihan pribadi, sanitasi lingkungan yang buruk, dan kurangnya fasilitas kesehatan yang dapat dijangkau oleh sebagaian besar masyarakat (Sulistia, 2016).

Penegakan diagnosis demam typhoid dilakukan secara klinis dan melalui pemeriksaan laboratorium. Pemeriksaannya dapat berupa pemeriksaan hematologi berupa darah lengkap, uji serologis, kultur dan biakan (Soegijanto, 2012). Salah satu metode serologi yang biasa digunakan dalam diagnosis demam typhoid adalah uji widal.

Uji Widal merupakan suatu pemeriksaan laboratorium untuk mendeteksi ada atau tidaknya antibodi pada penderita demam typhoid terhadap antigen Salmonella typhi yaitu antibodi terhadap antigen O (dari tubuh kuman), antigen H (flagel kuman), dan antigen Vi (kapsul kuman). Dari ketiga antibodi, hanya antibodi terhadap antigen $\mathrm{O}$ dan $\mathrm{H}$ yang mempunyai nilai diagnostik demam typhoid dengan jalan mereaksikan serum seseorang dengan antigen $\mathrm{O}$ dan antigen H (Entjang, 2003). Selain itu, Pemeriksaan hematologi berupa darah lengkap digunakan untuk menunjang diagnosa suatu penyakit dan atau untuk melihat bagaimana respon tubuh terhadap suatu penyakit (Jiwintarum et al., 2020). Pemeriksaan yang dilakukan yaitu hitung jumlah limfosit dan trombosit (Lesmana, 2009).

Obeagu Emmanuel Ifeanyi tahun 2014 dalam penelitiannya menyimpulkan bahwa nilai rata-rata (mean) jumlah limfosit pada penderita demam typhoid adalah $61 \%$ yang artinya mengalami peningkatan limfosit (limfositosis) dari 42 orang penderita demam typhoid dan menyimpulkan $\mathrm{P}$-value adalah $\mathrm{P}<0,05$ yang artinya terdapat hubungan. Berbeda dengan penelitian yang di lakukan oleh Billy Lesmana tahun 2009 di RS Immanuel Bandung pada pasien demam typhoid dengan pemeriksaan hitung jenis leukosit yang diperiksa sebanyak 28 orang menunjukkan subyek penelitian dengan limfopenia sebanyak 18 orang $(64,3 \%)$ limfosit normal sebanyak 9 orang $(32,1 \%)$, limfositosis sebanyak 1 orang $(3,6 \%)$ (Ifeanyi, 2014).

\section{Metode Penelitian}

Metode penelitian yang akan digunakan adalah observasional analitik, Sampel yang digunakan pada penelitian ini yaitu sebagian darah pada pasien demam typhoid di laboratorium Puskesmas Gunungsari Lombok Barat. Kriteria sampel yang digunakan sebagai berikut: 1) Darah dari penderita pasien demam typhoid. 2) Penderita demam typhoid dengan lama demam kurang dan lebih dari satu minggu. 3) Penderita demam typhoid dengan titer antigen O maupun antigen $\mathrm{H}$ diatas 1/80. Penelitian ini dilakukan uji Korelasi Pearson untuk mencari hubungan antara dua variable.

\section{Hasil Penelitian dan Pembahasan}

Tabel 1 Hasil Pemeriksaan Titer Widal O dengan Jumlah Limfosit dan Trombosit

\begin{tabular}{|c|c|c|c|c|c|c|}
\hline No & $\begin{array}{c}\text { Kode } \\
\text { sampel }\end{array}$ & $\begin{array}{c}\text { Titer widal } \\
\text { O }\end{array}$ & Limfosit (\%) & Rerata & $\begin{array}{c}\text { Trombosit } \\
(\mu L)\end{array}$ & Rerata \\
\hline 1 & S1 & $1 / 160$ & 9,0 & \multirow{5}{*}{24,84} & 581.000 & \multirow{5}{*}{312.000} \\
\hline 2 & S2 & $1 / 160$ & 17,1 & & 397.000 & \\
\hline 3 & S3 & $1 / 160$ & 22,1 & & 137.000 & \\
\hline 4 & S4 & $1 / 160$ & 29,0 & & 150.000 & \\
\hline 5 & S5 & $1 / 160$ & 47,0 & & 295.000 & \\
\hline 6 & S6 & $1 / 320$ & 34,6 & \multirow{8}{*}{43,95} & 196.000 & \multirow{8}{*}{230.750} \\
\hline 7 & S7 & $1 / 320$ & 37,3 & & 522.000 & \\
\hline 8 & S8 & $1 / 320$ & 38,0 & & 250.000 & \\
\hline 9 & S9 & $1 / 320$ & 38,3 & & 240.000 & \\
\hline 10 & S10 & $1 / 320$ & 38,7 & & 150.000 & \\
\hline 11 & S11 & $1 / 320$ & 44,4 & & 249.000 & \\
\hline 12 & $\mathrm{~S} 12$ & $1 / 320$ & 57,5 & & 145.000 & \\
\hline 13 & S13 & $1 / 320$ & 62,8 & & 94.000 & \\
\hline
\end{tabular}


Jurnal Analis Medika Biosains (JAMBS)

Vol.8, No.2, September 2021, pp. 77 - 80

ISSN: 2656-2456 (Online)

ISSN: 2356-4075 (Print)

Tabel 1 diperoleh titer tertinggi 1/320 dan titer terendah 1/160. Rerata jumlah limfosit dengan titer 1/160 adalah $24,84 \%$ dan titer $1 / 320$ adalah $43,95 \%$. Rerata jumlah trombosit dengan titer $1 / 160$ adalah $312.000 \mu \mathrm{L}$ dan titer $1 / 320$ adalah $230.750 \mu \mathrm{L}$.

Tabel 2 Hasil Pemeriksaan Titer Widal H dengan Jumlah Limfosit dan Trombosit

\begin{tabular}{|c|c|c|c|c|c|c|}
\hline No & $\begin{array}{c}\text { Kode } \\
\text { sampel }\end{array}$ & $\begin{array}{c}\text { Titer widal } \\
\mathrm{H}\end{array}$ & $\begin{array}{c}\text { Limfosit } \\
(\%)\end{array}$ & Rerata & $\begin{array}{c}\text { Trombosit } \\
(\mu \mathrm{L})\end{array}$ & Rerata \\
\hline 1 & S1 & $1 / 160$ & 19,5 & \multirow{6}{*}{35,48} & 53.000 & \multirow{6}{*}{196.670} \\
\hline 2 & $\mathrm{~S} 2$ & $1 / 160$ & 26,9 & & 293.000 & \\
\hline 3 & S3 & $1 / 160$ & 33,1 & & 190.000 & \\
\hline 4 & S4 & $1 / 160$ & 43,7 & & 215.000 & \\
\hline 5 & S5 & $1 / 160$ & 44,4 & & 249.000 & \\
\hline 6 & S6 & $1 / 160$ & 55,3 & & 180.000 & \\
\hline 7 & S7 & $1 / 320$ & 23,5 & \multirow[t]{5}{*}{39,86} & 135.000 & \multirow{5}{*}{158.000} \\
\hline 8 & S8 & $1 / 320$ & 34,6 & & 196.000 & \\
\hline 9 & S9 & $1 / 320$ & 38,7 & & 150.000 & \\
\hline 10 & S10 & $1 / 320$ & 43,0 & & 236.000 & \\
\hline 11 & S11 & $1 / 320$ & 59,5 & & 73.000 & \\
\hline
\end{tabular}

Tabel 2 diperoleh titer tertinggi 1/320 dan titer terendah 1/160. Rerata jumlah limfosit dengan titer 1/160 adalah $35,48 \%$ dan titer $1 / 320$ adalah $39,86 \%$. Rerata jumlah trombosit dengan titer $1 / 160$ adalah $196.670 \mu \mathrm{L}$ dan titer $1 / 320$ adalah $158.000 \mu \mathrm{L}$.

Tabel 3. Hasil Uji Statistik Titer widal dengan Jumlah Limfosit dan Trombosit Pasien Demam Typhoid

\begin{tabular}{|c|c|c|}
\hline & Limfosit & Trombosit \\
\hline & sig. & sig. \\
\hline Antigen & 0.758 & 0.098 \\
\hline Titer & 0.051 & 0.350 \\
\hline
\end{tabular}

Hasil uji Korelasi Person didapatkan hasil $p>\alpha=0,05$ pada pemeriksaan limfosit dengan antigen adalah $p=0,758$. Pemeriksaan trombosit dengan antigen adalah $p=0,098$. Pemeriksaan limfosit dengan titer adalah $p=$ 0,051. Pemeriksaan trombosit dengan titer adalah $p=0,035$. Hasil ini menunjukkan bahwa tidak terdapat hubungan yang signifikan, artinya bahwa $\mathrm{H} 0$ diterima dan $\mathrm{H} 1$ ditolak sehingga dapat dikatakan bahwa tidak ada hubungan titer widal dengan jumlah trombosit pada pasien demam typhoid.

Hasil penelitian menunjukan bahwa jumlah limfosit terhadap antigen $\mathrm{O}$ yang meningkat adalah 8 orang $(61,53 \%)$, Jumlah limfosit normal adalah 3 orang $(23,07 \%)$ dan jumlah limfosit rendah adalah 2 orang $(15,38 \%)$. Sedangkan pada antigen $\mathrm{H}$ didapatkan jumlah limfosit meningkat adalah 6 orang $(54,54 \%)$, jumlah limfosit normal adalah 4 orang $(36,36 \%)$ dan limfosit rendah adalah 1 orang $(9,09 \%)$. Setelah di uji analisis, didapatkan hasil tidak terdapat hubungan titer widal dengan jumlah limfosit pada penderita demam typhoid (Jiwantoro \& Jannah, 2019).

Jumlah limfosit yang bervariasi disebabkan beberapa faktor yaitu berkaitan dengan umur penderita dan lamanya demam yang dialami oleh penderita demam typhoid. Dalam penelitian ini, rata-rata penderita demam typhoid dengan lama demam kurang lebih satu minggu. Antibodi terhadap antigen O muncul pada hari ke 6 - 8 dan antibodi terhadap antigen $\mathrm{H}$ hari ke 10-12 setelah terpapar. Pada akhir minggu pertama sejak timbulnya gejala, kedua titer antibodi baik terhadap antigen $\mathrm{H}$ maupun $\mathrm{O}$ meningkat menjadi 1/160. Pembentukan antibodi mulai terjadi pada akhir minggu pertama demam, meningkat cepat sampai puncaknya di minggu keempat, dan tetap tinggi selama beberapa minggu (Renowati \& Soleha, 2019). 
Depresi sumsum tulang sering dikaitkan dengan demam typhoid yang mengakibatkan terjadi limfosit yang tinggi atau limfositosis (Lesmana, 2009). Beberapa faktor lain yang menyebabkan jumlah limfosit justru menurun adalah adanya infeksi lain yang dapat mengganggu kerja sumsum tulang, kondisi imunitas penderita dan invasi dari bakteri Salmonella typhi. Selain itu juga beberapa pasien didapatkan jumlah limfosit normal karena perbedaan respon imun pasien dan tingkat resistensi terhadap bakteri tersebut. Kasus ini menjadi menarik karena pada penelitian, sebagian hasil penghancuran Salmonella typhi dalam proses fagositosis pada akhir minggu kedua dapat dikatakan sudah tidak ditemukan lagi Salmonella typhi yang hidup dalam darah, namun masih ada dalam sumsum tulang (Handojo, 2004).

\section{Kesimpulan}

Rerata jumlah limfosit dengan antigen O (1/160) adalah 24,84\% antigen O (1/320) adalah 43,95\% dan antigen $\mathrm{H}(1 / 160)$ adalah 35,48\% antigen $\mathrm{H}(1 / 320)$ adalah 39,86\%. Rerata jumlah trombosit dengan antigen O (1/160) adalah 312.000 $\mu \mathrm{L}$ antigen $\mathrm{O}(1 / 320)$ adalah $230.750 \mu \mathrm{L}$ dan antigen $\mathrm{H}(1 / 160)$ adalah $196.670 \mu \mathrm{L}$ antigen $\mathrm{H}(1 / 320)$ adalah 158.000 $\mu \mathrm{L}$. Titer widal pada pasien demam typhoid adalah titer $\mathrm{O}$ terendah $1 / 160$ dan tertinggi 1/320. Titer H terendah $1 / 160$ dan tertinggi 1/320. Tidak terdapat hubungan antara titer widal dengan jumlah limfosit dan jumlah trombosit.

\section{Daftar Pustaka}

Entjang, I. (2003). Mikrobiologi Dan Parasitologi Untuk Akademi Keperawatan (2nd Ed.). PT Citra Aditya Bakti. Ifeanyi, O. E. (2014). Changes In Some Haematological Parameters In Typhoid Patients Attending University Health Services Department Of Michael Okpara University Of Agriculture, Nigeria. Journal Of Infection In Developing Countries, 8(1), 246-248.

Jiwantoro, Y. A., \& Jannah, M. (2019). Pengaruh Ekstrak Pegagan (Centella Asiatica (L.) Terhadap Profil Darah Dan Hepar Pada Tikus Putih Yang Diinduksi Asap Rokok. Jurnal Kesehatan Andalas, 2(1), 99.

Jiwintarum, Y., Srigede, L., \& Asyhaer, R. K. (2020). Hematocrite Values With High Measurement Of Eritrosit After Centrifugation On Serum Making. Jurnal Analis Medika Biosains (JAMBS), 7(2), 112.

Https://Doi.Org/10.32807/Jambs.V7i2.193

Lesmana, B. (2009). Gambaran Leukosit Dan Hitung Jenis Leukosit Pada Pasein Rawat Inap Demam Tifoid Dengan Gall Culture Positif Di RS Immanuel Periode Januari 2007-Juni 2008.

Maulida, H., Sri Wulan, W., \& Wahyuni, S. (2015). Hubungan Antara Jumlah Leukosit Dan Trombosit Pada Penderita Demam Typhoid. 4(2), 10-17.

Renowati, \& Soleha, M. S. (2019). Hubungan Uji Diagnostik Widal Salmonella Typhi Dengan Hitung Leukosit Pada Suspek Demam Tifoid Typhoid Fever Is A Systemic Infection That Causes Salmonella Typhi Bacteria Until Now Is Still A Problem In The World, Especially Indonesia Because Of Lack Of . 2(1), 123-128.

Soegijanto, S. (2012). Ilmu Penyakit Anak Diagnosis Dan Penatalaksanaan. Salemba Medika.

Sulistia, Y. (2016). Hubungan Jumlah Trombosit Cara Otomatik Dengan Pemeriksaan Salmonella Igg Dan Igm Rapid Pada Penderita Tifoid Skripsi. 